\title{
Analysis of Colonialist Tendency in Gulliver's Travels
}

\author{
Wu jin', a , Ding zhirui ${ }^{2, b}$ \\ ${ }^{1}$ Foreign Languages Department, Jilin University of Finance and Economics, \\ Changchun, 130117, China; \\ ${ }^{2}$ Foreign Language School, Jilin Agricultural University, Changchun, 130118, China; \\ a 41714453@qq.com, b41714453@qq.com
}

Keywords: colonialism, racism, cultural centre.

\begin{abstract}
Gulliver's travels are an excellent satirical novel in the neo classical period of English literature. While exposing the social problems in Britain, he criticized the prevailing colonialism. But the author himself was still limited by the times and had a certain colonial mentality. This paper interprets the background and content of the works and analyses the inner colonial ideology in the works.
\end{abstract}

\section{Historical background analysis of the novel}

Gulliver's Travels is a classical literary work by Jonathan Swift, a famous English writer. Jonathan Swift (1667-1745) was born in Dublin, Ireland (Chen Jun 2012). And he is the most outstanding England satirist in the 18the century (Chen Jun). Gulliver's Travels published in 1726, it is regarded as Swift's masterpiece (Wu Menasha, 2016). It was completed in the Neo classicism period of English literature. British social life in this period was very unstable, full of change and turbulence. After the glorious revolution in 1689, Puritan Princess Marie and William from Holland came to power, ascended the throne and established the British constitutional monarchy. After this, the two political parties in Britain struggled for the powder, which also led to the contradiction between Anglicans and non-Anglican. In eighteenth Century, Britain's national power developed rapidly, and many colonies were seized abroad. With the development of market and the raw material producing area, the traditional handicraft production methods cannot fully meet the demand of industrialized development. Therefore, during this period, with the enclosure movement continued to deepen, the labor force was thus liberated, and the industrial revolution in Britain also had a solid foundation. At the same time, the new British class has reached a peak for the aspirations for getting the vast colonies abroad. With the development of economy, the number of the bourgeoisie, especially the middle class, became more and more huge. These new emerging classes were distinguished from the traditional aristocracy, who pursued new life goals and believed in the code of conduct that had more characteristic of the times. They began to flaunt self-reliance, and work to become rich by themselves. Most of them considered that their lives were about working hard and accumulating wealth. These characteristics were reflected in the realistic novels at that time.

\section{Introduction of the novel}

Gulliver's travels is an outstanding satire in the history of English literature, using the writing form of travels. In the tone of the hero Gulliver, the book tells his readers about some strange experiences in the process of traveling around the world. The story began in 1699, when the protagonist, Gulliver, took the "antelope" to sea. Gulliver, with his gentle temperament, won the favor of the local people, learned the local language, and began to serve the emperor. At this time, another Lilliput (Blefuscu Empire) invaded from the sea. The 50 biggest enemy ships were towed back to the port by Gulliver's, which helped the Lilliput victory in the war. However, because there 
was no promise to destroy the Blefuscu, he offended the emperor totally. At this time, the palace of the queen caught a big fire, Gulliver showed his resourcefulness in an emergency to put out the fire with his own urine. The queen was not grateful to him, but she was very angry. So the whole country Lilliput began plotting to kill Gulliver. After he received the message, he escaped to Blefuscu Empire, found the way to leave there, and finally returned to Britain. Not long after he was back home, Gulliver went to sea again. Unfortunately, he met the storm again. The boat had drifted to the adult country (Bbu Loeb Martin inessive). When he was out looking for fresh water, he was caught by a farmer as high as 20 meters. In order to earn money, the farmer forced Gulliver to perform in the adult state, and later sold him to the queen. In the palace, Gulliver was very popular. But at the same time, he often suffered from rat or animal invasion. When Gulliver introduced the history and circumstances of Britain in the past hundred years with the voice of complacence, he was denied by the king. In his third year in this kingdom, Gulliver was caught by an eagle when he visited the border area with the king, and later was dropped into the sea and was rescued by an English ship and returned to his hometown.

After returning home, unable to bear the loneliness, before long Gulliver went to sea again. This time, his ship was hijacked by pirates. He escaped by himself and was rescued by a flying island. All the people on the flying island were kings and nobles, and the common people lived on the other three islands. People on the flying island were lost in thought all day. The Local Academy of sciences were studying some problems which were absurd. Then he visited the witch island again. The island's governor can summon ghosts, Gulliver also met many ancient celebrities, also found that a lot of historical records was actually wrong, even confusing the truth and falsehood. Finally, Gulliver went back to England via Japan. Five months later, he returned to sea as the the captain of "the adventure". This time he was quite surprised to come to a strange country Houy country. The Houys, Master like a horse, are the social creatures here, who had reason and wisdom. And they were also similar with a kind of draught animal- yahoos, which were actually a creature driven by the Houys cattle. Gref himself was considered as a rational yahoo because his behavior and conversation was always rational. Under the influence of various virtues from the Houys , he wanted to stay in this country. Nevertheless, ultimately, he can only take a small boat to return home reluctantly. After returning to the country, Gulliver made friends with horces only because of his missing o the Houys in the days of his rest life. The whole work expresses the author's own ideas and views through the adventures and encounters of the hero in the four strange countries that do not exist. The author revealed the corruption and darkness of the British ruling class, mercenary of the ruling group of the first half of the eighteenth Century to the readers deeply. To a certain extent, the author also showed the brutal colonial wars, which also reflects the attitude of colonial people against aggression.

\section{Colonialism in the novel}

Colonialism refers to that after the age of discovery, some small countries, regions and the nation were enslaved and exploited by the capitalist countries, through military, political and economic means, and were turned into their colony or semi colony. In addition, colonialism also covers cultural and ideological factors. The colonists infiltrated their culture, world outlook, values, and even religious beliefs into colonial rule and forced the colonists to accept them. Gulliver's travels were written in the era of colonial development. Swift himself was born in Ireland, Britain's first colony, and he himself took an active part in the political movement of Irish independence. Therefore, for the sake of colonialism, the author himself had a very deep understanding and experience. Gulliver, the hero, is a doctor with excellent personality and a certain knowledge of sailing and medicine. He became an adventurer for the sake of his family. In this era of growing colonial prosperity, the identity of adventurers was first widely recognized. This is a prominent feature of colonial times. Gulliver visited four countries with different characteristics. The king of the country Lilliput is moody and self-righteous. In the author's eyes, the country he shaped was ignorant, backward, and extremely lacking in modern civilization. This is to cater to the image of overseas nations in British citizen's eyes. In the author's writing, the dispute between the Lilliput 
and the neighbouring country originated from the different interpretations of the Alcoran by both sides. This is also the Eastern Islamic country in the author's imagination. The author did not have some insight into the knowledge of the eastern countries, but his depiction of these countries was not fit to be seen, which is no other than the reflection of his colonial self-superiority. In Brobdingnag, there are not too many laws, and the people in this country are full of pure and natural flavor. Swift also revealed and criticized various evils and injustices in Britain by means of the mouth of the king of the country. But his appreciation of the adult state is the simplicity and originality of the region, which reflects the feudalism and backwardness of the Brobdingnag. The cultural centralism of colonialism is also manifested clearly in this part.

In third volume, the protagonist in the Flying Island has a skin and appearance which are totally different from the European people. The people here are sunken in one eye and the other eye is looking at the sky. Like many Western works, Gulliver's travels also showed the alienation of nonwhite races. This kind of alienation can be said to be written in almost the whole work. It can be said that it was a double manifestation of colonialism and racism in this novel. Scientists in this country are fierce and stupid. The author intended to satire the pseudo-science in the Royal Academy. For example, scientists engaged in the flying island devote themselves to such kinds of ridiculous, fruitless and with scientific researches with no reality as extracting sun from cucumber and restoring feces to food. In addition, they also take violent means to deal with the local residents. If the people there are slightly rebellious, they will drive the flying island to block the sunlight and even press the flying island on the residents' head. These are the typical means for the colonization. They suppress the people of the colonial resistance miserably. In the last part of the novel, in the Houys, though the Houys represents the reason and wisdom, they still envy Gulliver's hand, which are white and tender. In the recognition of European colonists at that time, white skin was the symbol of European civilization. From this point, it is not difficult to see the unique racial superiority with the tendency of colonialism. The colonial tendency of this book is not only reflected in the unintentional decline of other regions and civilizations, but also the protagonist, Gulliver himself, is also a vested interest in colonial behaviour. He gets good returns every time he goes to sea, so he risks his life again and again. This was also the reflection of the mainstream mentality of the European colonists at that time.

\section{Conclusion}

The novel, not only has the profound ideological content, but also has a relatively perfect art form. First, Swift portrayed the realities of Britain at that time with imaginary plots and fantasy. At the same time, he also created a colourful fairy tale fantasy world based on the reality of Britain at that time. Swift's fantasy world was based on reality, while the reality of contradictions in the fantasy world was more concentrated. Gulliver's experiences in the Lilliput, Brobdingnag, the Flying Island and the Houys are quite different, but they are arranged in a reasonable way without any flaw. Gulliver's Travels is an excellent adventure novel and an excellent satirical novel. This work profoundly reveals the various problems of British society in the first half of the eighteenth Century, which makes readers see the evil and ugliness of the colonialists. However, the author's own times determines his limitations, at the same time with the satire on colonialism, the work also is deeply branded with colonialism.

\section{References}

[1]. Jonathan Swift, Gulliver's Travels [M]. Beijin, China Pictorial Publishing House, 2012.

[2]. Wu Mengsha. An Analysis of the Changes of Gulliver's Character in Gulliver's Travels [J]. Overseas English, 2016,11.

[3]. Chen Jun. Analysis to Satire in Jonathan Swift's Gulliver's Travels [J]. Overseas English [J], 2012,9. 